\title{
High Precision Hydrography in Canada, the ST. Lawrence River Channel, HD Bathymetry, Production, Distribution and Updating
}

Marc Journault Canada CHS, Louis Maltais Canada CHS, and

Richard Sanfaçon Canada CHS

Topic: C Innovations in processing techniques. The abstract received registration number 04.

INTRODUCTION

The St. Lawrence River channel (Quebec, Canada) is a 320km long navigation channel of which 210 $\mathrm{km}$ are maintained at minimum depth of $11.3 \mathrm{~m}$. Hydrographic surveys are conducted to exceed $\mathrm{S}-44$ special orders requirements. Centimeter level precision is constantly achieved in depth measurements with the survey boats. They are calibrated and their measurement of depths over the same seafloor has to be within a couple centimeters, at two sigma, to receive a green light for survey. The data used to establish the available water column are processed, validated and delivered within 24 hours.

The trend in commercial navigation in general is towards bigger, wider and faster ships. Therefore safely manoeuvering in restricted waters with limited water depth and limited width brings interesting challenges. With all the potential environmental impacts, there is a limit to deepening (dredging) and widening the navigation channel. Ships' drafts and widths are increasing but not necessarily the available depth and width of navigation channels; precise and up-to-date information is the solution. Forecasted water level and constant bathymetry updates are now requested by clients.

This paper will briefly describe the intense survey operations taking place in the St. Lawrence River channel, every year from April to December. Based on recent work at the Canadian Hydrographic Service (CHS) -Quebec Region, the paper is also proposing a new way to produce, distribute and update rapidly, High Definition (HD) bathymetric files using the navigation surface and S-102 tiles concept. This leads to a positive influence on the content of the $S-100$ standard series being developed and offering a solution to a fast turnaround from surveys to bridge for areas facing dynamic changes with a limited water column. A fast turnaround from surveys to bridge is essential for safer navigation and therefore helping taking care of the sea.

\section{THE REGION and THE NAVIGATION}

The Great Lakes - St. Lawrence Waterway is a vital link between the heart of industrial North America (highly industrialised and urbanised, $50 \mathrm{M}$ inhabitants, 4 of the 6 largest port installations in Canada) and international markets. This waterway is about $3600 \mathrm{~km}$ long from the Atlantic Ocean to the head of Lake Superior, the western most of the five Great Lakes. The St. Lawrence River is the eastern part of it, approximately $1800 \mathrm{~km}$ long, starting from Lake Ontario (the eastern most lake of the five) to the Atlantic Ocean. The cruise industry is growing and this is also where we find more than 20,000 ship movements registered per year, 30\% of the cargo handled in the country and several thousands recreationnal boats.

On this waterway, a portion located between Montréal and Le Massif (a winter ski resort near the shore, $80 \mathrm{~km}$ East of Québec City) is called The St. Lawrence River channel. This navigation channel is approximately $320 \mathrm{~km}$ long and silting is occuring in different areas all along the River channel. From downstream up, the width of the channel varies from $335 \mathrm{~m}$ to $310 \mathrm{~m}$ near Ile d'Orléans and then $240 \mathrm{~m}$ from Quebec City to Montreal. The size of the ships navigating the river is increasing and therefore ships' drafts and widths are increasing too, but not necessarily the available depth and width of navigation channels. Therefore constant monitoring of water depths and rapid updates of the information is getting more and more crucial. 


\section{THE STANDARDS for Hydrographic Surveys at CHS}

In the St. Lawrence River channel, the hydrographic surveys are regularly and systematically conducted to exceed S-44 special order requirements. In fact, the surveys are meeting Exclusive Order. In canadian standards, Exclusive Order hydrographic surveys are based on the International Hydrographic Organization (IHO) Special Order with higher accuracy and their use is intended to be restricted to shallow water areas (harbors, berthing areas and critical channels) where there is an optimal use of the water column and where specific critical areas with minimum under-keel clearance and bottom characteristics are potentially hazardous to vessels. This order also applies to high precision engineering surveys. All error sources must be minimized. Exclusive Order requires very precise positioning systems, and a rigorous control on all aspects of the surveys.

The use of side-scan sonar or multi-transducer arrays or high-resolution multi-beam echo sounders is required to survey the feature size to be detected. In required areas, appropriate sounding equipment and methodologies must be employed in order to ensure that all features greater than $0.5 \mathrm{~m}$ cubed are detected. The use of side-scan sonar in conjunction with multi-beam or multi-transducer echo sounders may be necessary in areas where pinnacles and dangerous obstacles may be encountered.

To accommodate different accuracy requirements for areas to be surveyed and to classify old surveys, six orders of survey are defined. These are described below and in Table 1 which summarize the overall accuracy requirements and constitute, in fact, the essence of the standards.

One other major difference with the IHO S44 is the way CHS classifies surveys. The classification is divided into four components: the horizontal accuracy, the vertical accuracy, the target detection capability and the type of coverage. For instance, a survey can attain an horizontal accuracy of Special Order, a vertical accuracy and a feature detection of Order 1 and the type of coverage could be 1 (complete coverage).

Table 1 Standards for Hydrographic Surveys

\begin{tabular}{|c|c|c|c|c|c|c|}
\hline ORDER & Exclusive & Special & 1 & 2 & 3 & $\begin{array}{c}4 \\
\text { (Imprecise) }\end{array}$ \\
\hline $\begin{array}{l}\text { Examples of } \\
\text { Typical areas }\end{array}$ & $\begin{array}{l}\text { Shallow water } \\
\text { in harbours, } \\
\text { berthing areas, } \\
\text { and associated } \\
\text { critical channels } \\
\text { with minimum } \\
\text { under-keel } \\
\text { clearances or } \\
\text { engineering } \\
\text { surveys }\end{array}$ & $\begin{array}{l}\text { Harbours, } \\
\text { berthing } \\
\text { areas, and } \\
\text { associated } \\
\text { critical } \\
\text { channels } \\
\text { with } \\
\text { minimum } \\
\text { under-keel } \\
\text { clearances }\end{array}$ & $\begin{array}{l}\text { Harbours, } \\
\text { harbour } \\
\text { approach } \\
\text { channels, } \\
\text { recommended } \\
\text { tracks and some } \\
\text { coastal areas } \\
\text { with depths up to } \\
100 \mathrm{~m}\end{array}$ & $\begin{array}{l}\text { Areas } \\
\text { up to } \\
200 \mathrm{~m} \\
\text { water } \\
\text { depth }\end{array}$ & $\begin{array}{l}\text { Offshore } \\
\text { areas not } \\
\text { described } \\
\text { in the } \\
\text { previous } \\
\text { orders }\end{array}$ & $\begin{array}{l}\text { All areas where } \\
\text { the accuracies } \\
\text { do not meet } \\
\text { the } \\
\text { requirements of } \\
\text { the previous } \\
\text { orders }\end{array}$ \\
\hline \begin{tabular}{|l|l} 
& Horizontal \\
Accuracy \\
$(95 \%$ \\
Confidence \\
Level)
\end{tabular} & $1 m$ & $2 m$ & $\begin{array}{l}5 m+5 \% \text { of } \\
\text { depth }\end{array}$ & $\begin{array}{l}20 \mathrm{~m} \\
+5 \% \\
\text { of } \\
\text { depth }\end{array}$ & $\begin{array}{l}150 m+ \\
5 \% \text { of } \\
\text { depth }\end{array}$ & $\begin{array}{l}>150 m+5 \% \\
\text { of depth }\end{array}$ \\
\hline$V \mid \begin{array}{l}\text { Depth } \\
\text { Accuracy for } \\
\text { Reduced } \\
\text { Depths } \\
\text { (95\% } \\
\text { Confidence }\end{array}$ & $\begin{array}{l}a=0.15 \mathrm{~m} \\
b=0.0075\end{array}$ & $\begin{array}{l}a=0.25 \mathrm{~m} \\
b=0.0075\end{array}$ & $\begin{array}{l}a=0.5 \mathrm{~m} \\
b=0.013\end{array}$ & $\begin{array}{l}a= \\
1.0 m \\
b= \\
0.023\end{array}$ & $\begin{array}{l}\text { Same as } \\
\text { Order } 2\end{array}$ & $\begin{array}{l}>\text { than values } \\
\text { of order } 2\end{array}$ \\
\hline
\end{tabular}




\begin{tabular}{|c|c|c|c|c|c|c|}
\hline ORDER & Exclusive & Special & 1 & 2 & 3 & $\begin{array}{c}4 \\
\text { (Imprecise) }\end{array}$ \\
\hline
\end{tabular}

\begin{tabular}{|c|c|c|c|c|c|c|c|}
\hline$D$ & $\begin{array}{l}\text { System } \\
\text { Detection } \\
\text { Capability } \\
\end{array}$ & $\begin{array}{l}\text { Features }> \\
0.5 m \text { cubed }\end{array}$ & $\begin{array}{l}\text { Features }> \\
1 m \text { cubed }\end{array}$ & $\begin{array}{l}\text { Features }>2 \mathrm{~m} \text { cubed in depths up } \\
\text { to } 40 \mathrm{~m} ; 10 \% \text { of depth beyond } 40 \mathrm{~m} \\
\text { (2) }\end{array}$ & $N / A$ & $N / A$ & $N / A$ \\
\hline & \multicolumn{7}{|c|}{ Type of coverage (M270) } \\
\hline & \multicolumn{7}{|c|}{ 1. complete coverage (multi-beam, multi-transducer, acoustically swept); } \\
\hline & \multicolumn{7}{|c|}{$\begin{array}{l}\text { 2. systematic survey (single-beam echo sounder lines run parallel at pre-planned line spacing, } \\
\text { LiDAR); }\end{array}$} \\
\hline & \multicolumn{7}{|c|}{ 3. sparse coverage (lead-line surveys, reconnaissance, track soundings, spot soundings); } \\
\hline
\end{tabular}

(1)To calculate the error limits for depth accuracy the corresponding values of $a$ and $b$ listed in Table 1 have to be introduced into the formula

$\pm \sqrt{ }\left[a^{2}+(b \times d)^{2}\right]$

where

a: constant depth error, i.e. the sum of all constant errors in metres

$b \times d:$ depth dependent error, i.e. the sum of all depth dependent errors

$b$ : factor of depth dependent error

d: depth in metres

(2) The value of $40 \mathrm{~m}$ has been chosen considering the maximum expected draft of vessels.

The rows of Table 1 are explained as follows:

Row 1 "Examples of Typical Areas" gives examples of areas to which an order of survey might typically be applied.

Row 2 "Horizontal Accuracy" lists minimum positioning accuracy for each depth sounding to be achieved to meet each order of survey.

Row 3 "Depth Accuracy" specifies parameters to be used to calculate minimum accuracy of reduced depths to be achieved to meet each order of survey.

Row 4 "System Detection Capability" specifies the detection capabilities of systems used when 100\% bottom search is required.

Row 5 "Coverage type" specifies the seabed coverage based on the system and the methodology used to achieve a survey.

Row 6 "Maximum Line Spacing" is to be interpreted as:

- Spacing of sounding lines for single beam sounders and spot soundings surveys.

This table gives the different accuracy requirements for different areas to be surveyed according to a specific order of precision. The highest accuracy requirements are found in Exclusive Order while the least order of precision is given in Order 4.

\section{THE FIELD OPERATIONS and SURVEYS RESULTS}

From the $320 \mathrm{~km}$ long St. Lawrence River Channel, approximately $210 \mathrm{~km}$ are maintained at a minimun depth of $12.5 \mathrm{~m}$ to $11.3 \mathrm{~m}$ (depending on the sectors) while proceeding more inland. The channel is divided in 5 sectors $(C, D, E, F, G)$. In these sectors, three surveys boats operate during the ice-free season, from mid-April to end of November. Two of those boats are catamaran equipped with sweep 
systems and the third one is an 8 meter long aluminum launch (Lifetimer) equipped with a R2-Sonic 2022 multibeam echosounder. We are also evaluating the Kongsberg EM2040 and the Reson 7025 during 2012 survey season. It's our intention, in the short term, to replace the traditonnal Navitronics sweep systems of the 2 catamarans by multibeam echosounder sytems.

Each day, the survey boats are assigned a sector to be surveyed. Two hydrographers are taking place in the boat controlling the acquisition of data and processing it in near real time. At the end of the day, a final check is done and minutes later the clean file is sent to the client, Waterways Management Division at the Canadian Coast Guard. The morning after an other sector is assigned to the boats and the process is repeated 4 or 5 days a week (depending on the boat) for the whole season.

Survey results give the most recent picture of the seafloor details. Using a full bottom coverage acoustic system like multibeam sonars, we generate high definition gridded bathymetry(HDGB). The $H D$ simply refers to a much higher resolution than what is presented on the chart. For example, the resolution of the data coming from a MultiBeam Echosounder System (MBES) could be the insonified footprint on the seafloor. Using the CUBE processing method incorporated in CARIS HIPS, we deliver on a daily basis bathymetric surfaces to our internal clients. The gridded bathymetry can be described as a Navigation Surface (in marine environnement, a Digital Terrain Model ). These gridded bathymetric datasets are generally used for chart compilation, volume computation and visualisation but can also be a basic navigation product by itself.

\section{NEW PRODUCTS in LINE with S-100}

To develop a HDGB product for navigation, CHS adopted a collaborative approach where navigators and software manufacturers were informed and consulted for specifications of a future product. For consultation, prototype datasets were produced and made available in a simple format for experimentation and trials.

The work of the IHO Transfer Standard Maintenance and Application Development working group (TSMAD) on the new Geospatial Standard for Hydrographic Data (S-100) was promising and CHS decided to embark. The CHS and the United States NAVal Oceanographic office (NAVO) worked together to draft and propose a product specification for gridded bathymetry based on previous work done by the Open Navigation Surface group. The standard is named Bathymetric Surface Product Specification and identified as $S-102$.

The Hydrographic Services and Standards Committee (HSSC) approved the final draft of S-102 in November 2011. It also instructed the International Hydrographic Bureau (IHB) to submit it to Member States for their endorsement. Subsequently the IHO Circular letter 10/2012 requested the Member States to review and consider the draft edition of S-102 which is available on the IHO website.

To partition HDGB coverage, to allow unambiguous dataset exchange and to facilitate the updates, CHS intends to implement a systematic tiling scheme with three levels of resolution. Each tile is comprised of 1000 by 1000 grid cells, the level 1 (harbour) is $0.02^{\circ} \times 0.02^{\circ}$, the level 2 (coastal) is $0.1^{\circ} \times 0.1^{\circ}$, and the level 3 (overview or offshore) is $1^{\circ} \times 1^{\circ}$. For the below and mid latitudes, the orientation of the tiles fit the meridians and parallels with an origin based on a round number in latitude and longitude. Figure 1 shows an example of the tiling scheme. 


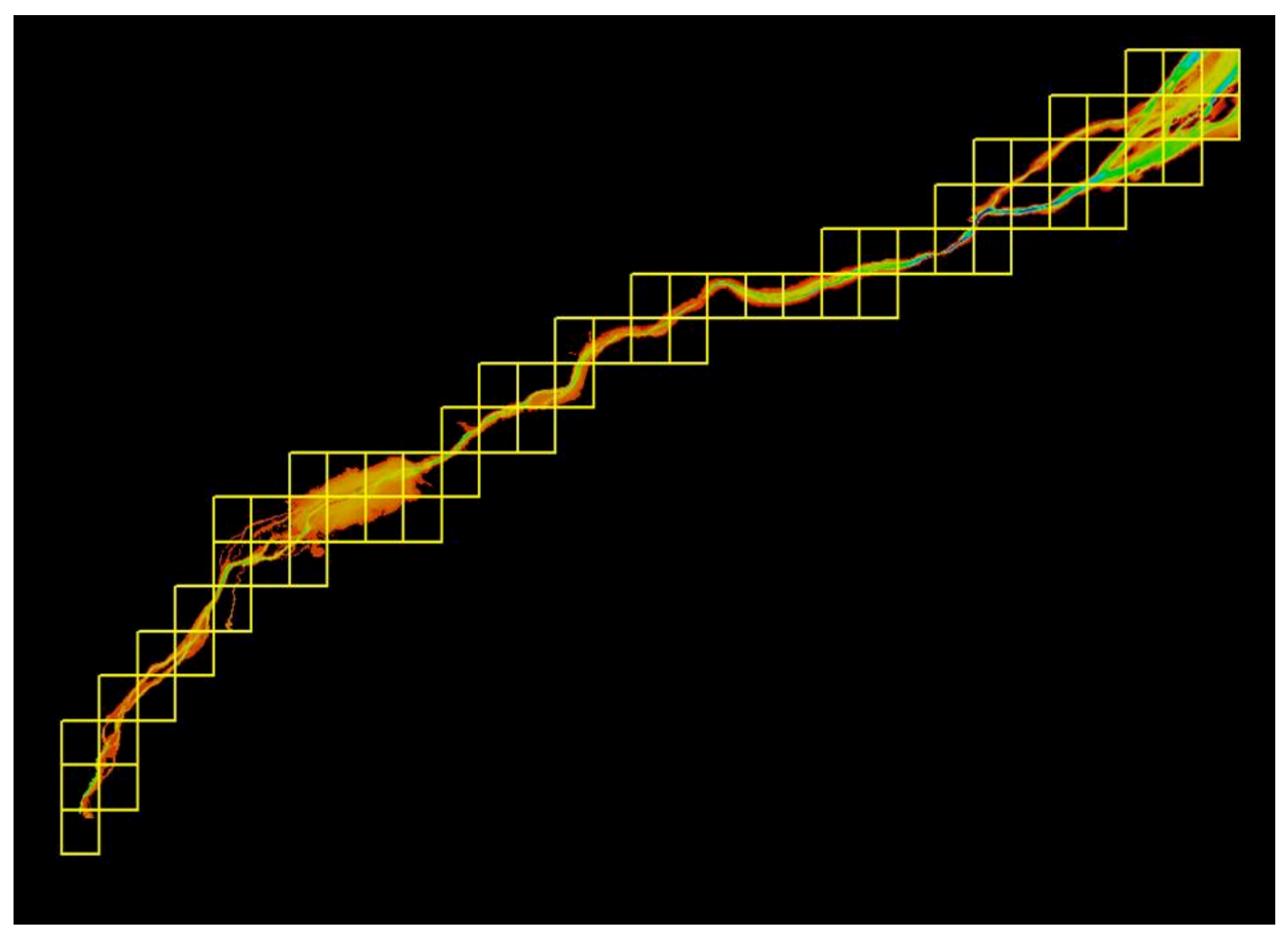

Figure 1: Level 2 (coastal) grid cells of $0.1^{\circ} \times 0.1^{\circ}$ for the St. Lawrence River channel

\section{UPDATES of the PRODUCTS}

It will be easy, with S-102, for hydrographers to provide navigators with HDGB datasets very rapidly to enrich and complement the information of their ENCs. Partitioned into standardised regular geographic cells, the provision of updates becomes easy by just supplying an entire new cell dataset with the new bathymetry to the users who then just supersedes the tile. A possible way to use HDGB for navigation is to put the $S-102$ data in the background with an overlap of S-101 without the display of S-101 soundings, depth areas and contours. Figure 2 is showing an example. 


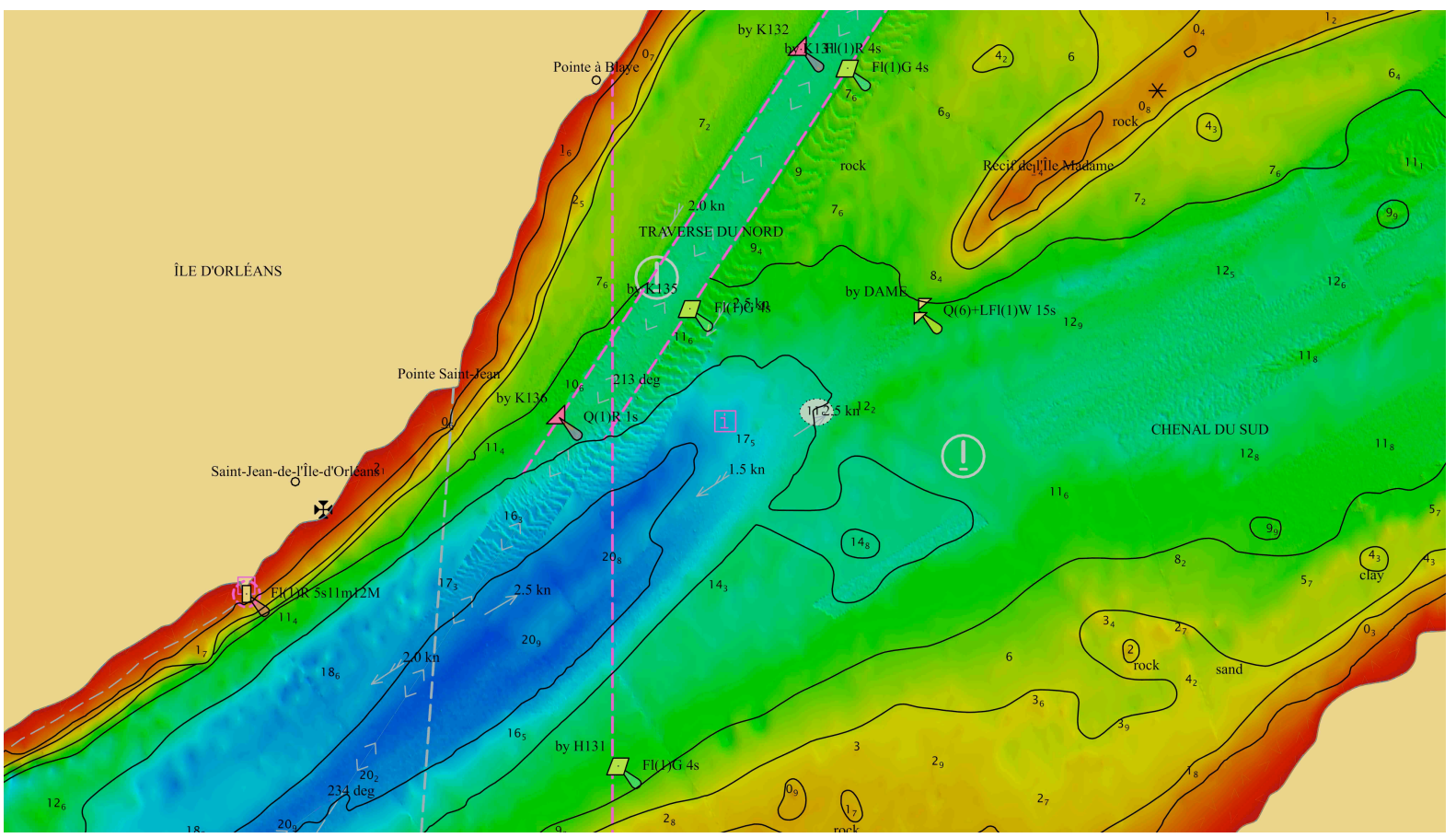

Figure 2: S-102 data in the background with an overlap of S-101, St. Lawrence River channel, SouthEast of Île d'Orléans

Electronic chart systems manufacturers can do a lot more than just displaying it. The HDGB can be used: to generate safety contour on the fly, to compute the available water column by the addition of water level (tidal data) on top of the bathymetry, to calculate a dynamic under keel clearance, etc. The exploitation of HDGB in an innovative way is left to the users and the software industry. The CHS wish to involve its partners at an early stage of design to consider feedback provided by the users communities and therefore make appropriate adjustements if needed.

\section{CONCLUSION}

High precision hydrography is present in St. Lawrence river Channel and in most areas in the world where intense commercial navigation occured in restricted waters with limited water depth and limited width. The data collected is powerful information to enhance efficiency and safety of navigation but unfortunately it does not make its way with its full potential to the mariners navigating these areas.

The advent of new hydrographic products in line with S-100 and the proposed S-102 product specification for High Definition Gridded Bathymetry is a solution to change this situation. The CHS development work and its intention to implement the systematic tiling scheme with three levels of resolution represent a good improvement and step ahead in trying to provide the mariners with better information. It will lead not only to a faster and more complete turnaround from surveys to bridge which is essential for safer navigation but it will also help taking care of the sea. 


\section{BIOGRAPHIES}

Marc JOURNAULT has been working for the Canadian Hydrographic Service for 29 years. He is manager of the Quebec Region's Data \& Support Division, responsible for technological support and data mangement in the fields of hydrographic surveys, nautical puublications and marine services.

Louis MALTAIS has been working for the Canadian Hydrographic Service for 14 years. He is a project ingineer involved in numerous $R \& D$ projects, implementing solutions to improve productivity, efficiencies and to better meet the clients needs.

Richard SANFAÇON has been working for the Canadian Hydrographic Service for 33 years. He is manager of the Quebec Region's Hydrographic Operations, responsible for hydrographic surveys and marine charts production. 
CONTACT DETAILS (of corresponding author only)

Richard SANFAÇON

Canadian Hydrographic Service

Institut Maurice-Lamontagne

C.P 1000,850 de la Mer

Mont-Joli

CANADA

Tel.: 418-775-0517

Fax: 418-775-0654

Email: richard.sanfacon@dfo-mpo.gc.ca

Web site: www.cartes.gc.ca

LinkedIn account:

Facebook account:

Twitter account:

\section{APPENDIX}

Submit you conference paper to submissions@hydro12.com. Include all files (including graphical files, and/or a pdf) in a single email. Your deadline is $\mathbf{1 5}$ June 2012. If your paper is not according to this template, or if the quality of your paper is poor, we reserve the right to refuse it. You are supposed to present the conference paper, either in an oral presentation, a poster presentation, or a tutorial session. If your paper is refused, or if no paper is submitted, it cannot be presented. Please contact us immediately if you expect any complications with your paper.

When you submit your paper, you should have the consent of all authors, and all your affiliations. Also, you should not submit before you have the approval of all the involved parties, including parties that own rights on the quotes, images and the data that you have used. Submissions should be done by the corresponding author only.

The authors, the title, and the contents of the paper should match the abstract. If the authors, their order, the corresponding author, or the presenting author change, please contact us immediately. Minor changes in the title and the contents, and the addition of authors, are allowed. 